\title{
Prospects of Russian Automobile Industry Development
}

\author{
Ajupov A. A. ${ }^{1}$, Kurilova A. A. ${ }^{2}$, Kurilov K. Yu. ${ }^{2} \&$ Bogatirev V. D. ${ }^{3}$ \\ ${ }^{1}$ Kazan Federal University, Institute of Management, Economics and Finance, Kazan, Russia \\ ${ }^{2}$ Togliatti State University, Togliatti, Russia \\ ${ }^{3}$ Samara State Aerospace University, Samara, Russia \\ Correspondence: Kurilova A. A., Togliatti State University, Togliatti, 445667, Russia. Tel: 79-17-122-3879. \\ E-mail: aakurilova@yandex.ru
}

Received: March 10, 2015 Accepted: March 31, 2015 Online Published: April 30, 2015

doi:10.5539/ass.v11n11p168 URL: http://dx.doi.org/10.5539/ass.v11n11p168

\begin{abstract}
The article comprises the results of the SWOT analysis of the Russian automotive industry, identified key opportunities, threats, strengths and weaknesses and set strategic goals for further development. The article presents the results of grouping of the world's car manufacturers based on the matrix of the Boston consulting group on two criteria - market share and market share growth of the company.
\end{abstract}

Keywords: the automotive industry, strategic priorities, vehicles, Russia

\section{Introduction}

The Russian economy is industry, which, despite the many assumptions and favorable conditions, cannot reach the level of international competitiveness. One such industry is the automotive industry. However, the existing potential, as well as access to the domestic market of the world's leading players create favorable conditions for the development of the domestic automotive industry.

The automotive industry is the leading sector of the domestic engineering industry, which determines the level of economic and social development of the country.

The situation in the Russian automotive industry in the past few years can be described as mixed. On the one hand, there is a rapid growth of the market, caused by, inter alia, increasing the purchasing power of the population, the development of consumer credit and the strengthening of the national currency. On the other hand, is constantly declining share of domestic manufacturers in the automotive market, while enhancing competition within price segments.

World experience of recent years shows that the coordination of efforts in this field can lead to very large-scale results. This is evidenced by the experience of similar industries of Korea and China. Over the past few years, cars in these countries are competitors' cars recognized industry leaders - Germany, France and the United States.

\section{Theory}

Basis for the development of the financial mechanism of management are priorities for the development of the automotive industry. One of the most common tools prioritization of the industry is to analyze the opportunities and threats of the external environment, as well as the strengths and weaknesses of the object of analysis, i.e., SWOT-analysis. In the course of analysis were used: a methodology for coordination of expert estimates, the approved strategy of the automotive industry and the work of M. Kuznetsov, which allowed us to obtain a generalized opinion of competent experts on the degree of the influence of external and internal factors.

Terms of impact on the competitive position of the object factors were divided into three groups:

- With a strong influence (1st level);

- With a moderate influence (2nd level);

- With a weak influence (3rd level).

For the automotive industry has been built following table features. 
Table 1. Opportunities in the automotive industry

\begin{tabular}{lll}
\hline First level & Second level & \multicolumn{2}{l}{ Third level } \\
\hline - Attracting foreign suppliers to operate & - The potential legislative support & - Development of additional \\
in an emerging market. & environmental focus in the & lines of business (financial \\
- Restructuring of the business and focus & $\begin{array}{l}\text { development of the automotive } \\
\text { market in Russia. }\end{array}$ & $\begin{array}{l}\text { products, spare parts sales } \\
\text { on core competencies. }\end{array}$ \\
- Introduction of new technologies with & - Increasing the options for \\
a high level of automation and low & $\begin{array}{l}\text { configuration (engine, transmission, } \\
\text { resource consumption production. }\end{array}$ & other accessories). \\
- Output to the world markets. & - Development of specialized training \\
- Preparation of a dealer network for & $\begin{array}{l}\text { at the base of higher educational } \\
\text { institutions and manufacturing plants. }\end{array}$ \\
sales in foreign markets. & - Increased market for domestic cars. \\
- Construction of new plants. &
\end{tabular}

To identify the main threats for the analysis of which is filled with the corresponding table.

Table 2. Threats of motor vehicle manufacturers

\begin{tabular}{|c|c|c|}
\hline First level & Second level & Third level \\
\hline $\begin{array}{l}\text { - Competitive displacement of domestic production } \\
\text { development (problems with the quality, cost, } \\
\text { consumer properties, update period). } \\
\text { - Reduction of the purchasing power of the } \\
\text { population. } \\
\text { - Increasing dependence on foreign domestic car } \\
\text { industry components. } \\
\text { - Low attractiveness of engineering work - the lack } \\
\text { of labor market skilled workers. } \\
\text { - The devaluation of the ruble. } \\
\text { - Advance cheaper imports. } \\
\text { - Lowering the level of public investment to } \\
\text { support the domestic automotive industry. } \\
\text { - Increased environmental regulations. } \\
\text { - Reorientation of the population in an } \\
\text { environmentally friendly form of transport. }\end{array}$ & $\begin{array}{l}\text { - Increasing disparities of regional } \\
\text { economies in the regions, mainly } \\
\text { dependent on imported vehicles } \\
\text { (failure repair, dealer network, etc.). } \\
\text { - The concentration of foreign } \\
\text { companies in engineering products } \\
\text { produced in the territory of the } \\
\text { Russian Federation, in the } \\
\text { traditional centers of technical } \\
\text { competence of these enterprises. } \\
\text { - The negative image of the } \\
\text { domestic automotive industry. } \\
\text { - Appreciation of components from } \\
\text { suppliers. } \\
\text { - Lowering of Russia's investment } \\
\text { rating }\end{array}$ & $\begin{array}{l}\text { - Increased service } \\
\text { networks of foreign } \\
\text { competitors. }\end{array}$ \\
\hline
\end{tabular}

In the next stage of the SWOT-analysis study was conducted of the internal environment of the object of analysis, which allowed the identification of strengths and weaknesses. The result is a table of strengths and weaknesses. Strengths / weaknesses are placed in the columns of the table depending on the degree of their influence on changes in the competitiveness of the object of analysis.

For domestic enterprises automotive industry we identified the following strengths.

Table 3. Strengths of Motor Vehicle Manufacturers

\begin{tabular}{|c|c|c|}
\hline First level & Second level & Third level \\
\hline $\begin{array}{l}\text { - An extensive service and distribution } \\
\text { network in the country, as well as the } \\
\text { simplicity of the design that is available for } \\
\text { your own repair buyer. } \\
\text { - The relatively low market value of cars } \\
\text { produced in Russia. } \\
\text { - The presence of large production facilities, } \\
\text { infrastructure and technical center, which } \\
\text { has the expertise and resources to prepare } \\
\text { for the production and maintenance of the } \\
\text { mass production of cars. }\end{array}$ & $\begin{array}{l}\text { - High availability of spare parts } \\
\text { in the market for domestic cars. } \\
\text { - Diversification of the lineup due } \\
\text { to "industrial assembly" foreign } \\
\text { brands. } \\
\text { - Potential for the use of modern } \\
\text { technology design. } \\
\text { - Low average monthly salaries. }\end{array}$ & $\begin{array}{l}\text { - Interchangeability of } \\
\text { nodes in different models of } \\
\text { cars of domestic production } \\
\text { (high unification). } \\
\text { - Focus on European } \\
\text { technical legislation to } \\
\text { ensure that exports to the } \\
\text { EU. }\end{array}$ \\
\hline
\end{tabular}


In accordance with the identified strengths of the table is filled with weaknesses in the automotive industry.

Table 4. Weaknesses in the automotive industry

\begin{tabular}{|c|c|c|}
\hline First level & Second level & Third level \\
\hline $\begin{array}{l}\text { - High impact on the financial risks of an } \\
\text { enterprise. } \\
\text { - High resource intensity of domestic cars. } \\
\text { - Reducing the cost of the automotive industry. } \\
\text { - Low export. } \\
\text { - Outdated production equipment. } \\
\text { - Outdated standards and technology design, } \\
\text { long-term development. } \\
\text { - Poor quality of products } \\
\text { - Low level of automation. } \\
\text { - Lack of own database engine. } \\
\text { - Low quality components and spare parts. }\end{array}$ & $\begin{array}{l}\text { - Low level of output per person } \\
\text { employed in the industry. } \\
\text { - Narrow range and a weak lineup update } \\
\text { - Rising costs in the price of a domestic } \\
\text { car for a given level of quality } \\
\text { - Low level of security of domestic cars. } \\
\text { - Low cost of research and development. } \\
\text { - Weak engineering support from } \\
\text { traditional suppliers. } \\
\text { - Lack of advertising and PR-campaigns } \\
\text { to create and maintain the image of the } \\
\text { domestic car. }\end{array}$ & $\begin{array}{l}\text { - Territorial } \\
\text { localization } \\
\text { automakers. } \\
\text { - The lack of a } \\
\text { priority goal of } \\
\text { environmentally } \\
\text { friendly transport. }\end{array}$ \\
\hline
\end{tabular}

At the last stage of the SWOT-analysis external opportunities and threats compared with the inner potential and limitations of the object of analysis. This allows you to determine the ability of the object of analysis to take advantage of opportunities and minimize the negative impact of external threats. The joint analysis addresses the following four combinations of groups of factors:

1. Strengths and opportunities.

2. Weaknesses and opportunities.

3. Strengths and threats.

4. Weaknesses and threats.

In each of the 4 groups of factors are considered only meaningful combinations thereof, that is, the combination of which could have a significant impact on the change in the competitive position in the automotive industry.

The analysis revealed the main direction prioritized into three groups:

1. The strategic priorities of the first level - the most important and relevant determining the competitiveness and viability of the domestic automobile enterprises in the future.

2. The strategic priorities of the second level - are needed to improve the competitiveness as mobilizing the required resources.

3. The strategic priorities of the third level - the priorities to identify current activities automotive industry.

Identified strategic priorities were indications that the formation of the financial management mechanism based on the identified priorities will contribute to solving the problems of the domestic automotive industry.

Table 5. Strategic priorities of domestic enterprises automotive industry

\begin{tabular}{|c|c|c|}
\hline Firs & & \\
\hline $\begin{array}{l}\text { - Reducing costs of domestic automobile } \\
\text { enterprises for a given level of quality; } \\
\text { - Reducing financial risks; } \\
\text { - Increasing share of domestic } \\
\text { automakers in total sales of motor } \\
\text { vehicles on the Russian market; } \\
\text { - Increase in the value of the enterprise; } \\
\text { - Access to world financial markets; } \\
\text { - To ensure the cost of production; } \\
\text { - Attracting foreign suppliers; } \\
\text { - Renovation of production facilities; }\end{array}$ & $\begin{array}{l}\text { - Improving the quality, availability of } \\
\text { spare parts and service for cars of } \\
\text { domestic production; } \\
\text { - Expansion of the model range; } \\
\text { - Increase the level of safety of } \\
\text { domestically produced vehicles; } \\
\text { - Increase the overall production capacity } \\
\text { of the Russian motor; } \\
\text { - Ensuring the circulation of securities of } \\
\text { domestic manufacturers in the global } \\
\text { financial markets; } \\
\text { - Implementation of programs of export }\end{array}$ & $\begin{array}{l}\text { - Preparation of the } \\
\text { dealer network for sales } \\
\text { in foreign markets; } \\
\text { - Advertising the } \\
\text { achievements of the } \\
\text { domestic auto industry; } \\
\text { - Increasing the options } \\
\text { for configuration } \\
\text { (engines, transmission, } \\
\text { other accessories); } \\
\text { - Development of } \\
\text { additional business }\end{array}$ \\
\hline
\end{tabular}


- Improving the quality of domestic cars by world standards;

- Implementation of new automotive technologies with a high level of automation and low resource consumption of production;

- Business restructuring and concentration on core competencies. of domestic cars;

areas.

- Development and implementation of training programs necessary skills for the automotive industry;

- The development of vehicles running on alternative energy sources;

- Environmental orientation in the development of the automotive market.

Draw a grouping of car manufacturers on the most essential features of evaluating the characteristics of automotive industry in various countries.

If we turn to the practice of business management, then to assess the situation of the company in the market and its success is commonly used matrix Boston Consulting Group BCG, which is a ranking of companies based on two criteria - the market share and growth in market share of the enterprise.

This allows you to evaluate the activity of the enterprise and offer a unified strategy for its further development. In our opinion, the same approach can be applied to groups of car manufacturers.

To improve the objectivity of the evaluation, in the formation of groups will use the methodology of cluster analysis, i.e. a set of methods for classifying multivariate observations or objects based on the definition of the distance between objects, followed by separation of these groups of observations (clusters). Distance between the objects defined using the Euclidean distance formula, which is calculated by the formula:

$$
p_{E}\left(x_{i}, x_{j}\right)=\sqrt{\left(x_{i}^{1,2, \ldots, k}-x_{j}^{1,2, \ldots, k}\right)^{2}}
$$

where $x_{i}^{1,2, \ldots, k}$ and $x 1,2, \ldots, k$ - values of the parameters characterizing the objects $x_{j}$ and $x_{j}$. Selection groups will be carried oult with the help of the principle of "nearest neighbor", and to improve the $j_{\text {information }}$ content and accuracy of classification - a number of indicators that assess the state of the automotive industry of a country.

The indicators suggest the use of parameters that characterize the country of manufacture of cars on its dynamics and the share of production auto structure. The complex such indices shown in Table 6.

Table 6. A set of indicators for the cluster analysis

\begin{tabular}{cccccc}
\hline Country-car & $\begin{array}{c}\text { Average } \\
\text { growth rate in } \\
\text { two years }\end{array}$ & $\begin{array}{c}\text { the proportion of } \\
\text { specific growth rate in } \\
\text { the total growth }(\%)\end{array}$ & $\begin{array}{c}\text { share on the } \\
\text { world market } \\
(\%)\end{array}$ & $\begin{array}{c}\text { Manufacture of } \\
\text { motor vehicles } \\
\text { per } 100 \text { persons }\end{array}$ \\
\hline 1 & Austria & 39,95 & 1,9 & 0,377 & 3,090 \\
2 & Belgium & 1,37 & 0,4 & 1,381 & 8,950 \\
3 & Finland & 29,70 & 0,0 & 0,032 & 0,414 \\
4 & France & $-0,96$ & $-1,2$ & 5,278 & 5,830 \\
5 & Germany & 2,26 & 4,2 & 8,562 & 6,986 \\
6 & Italy & $-11,33$ & $-4,8$ & 1,544 & 1,786 \\
7 & The Netherlands & $-6,00$ & $-0,6$ & 0,269 & 1,096 \\
8 & Portugal & $-4,31$ & $-0,3$ & 0,326 & 2,066 \\
9 & Spain & $-4,60$ & $-4,7$ & 4,093 & 6,813 \\
10 & Sweden & 2,42 & 0,3 & 0,503 & 3,755 \\
11 & United Kingdom & $-1,17$ & $-0,7$ & 2,681 & 2,975 \\
12 & Czech Republic & 18,21 & 2,8 & 0,900 & $\ldots$ \\
$\ldots$ & $\ldots$ & $\ldots$ & $\ldots$ & & 5,910 \\
\hline
\end{tabular}

To analyze the data using the company car manufacturers OCIA production cars in 53 countries for the period 2006-2012 and data on the number provided by the CIA in release of The World Factbook

The use of cluster analysis for the reduced sample gives the final matrix of the partition as shown in Figure 1. 


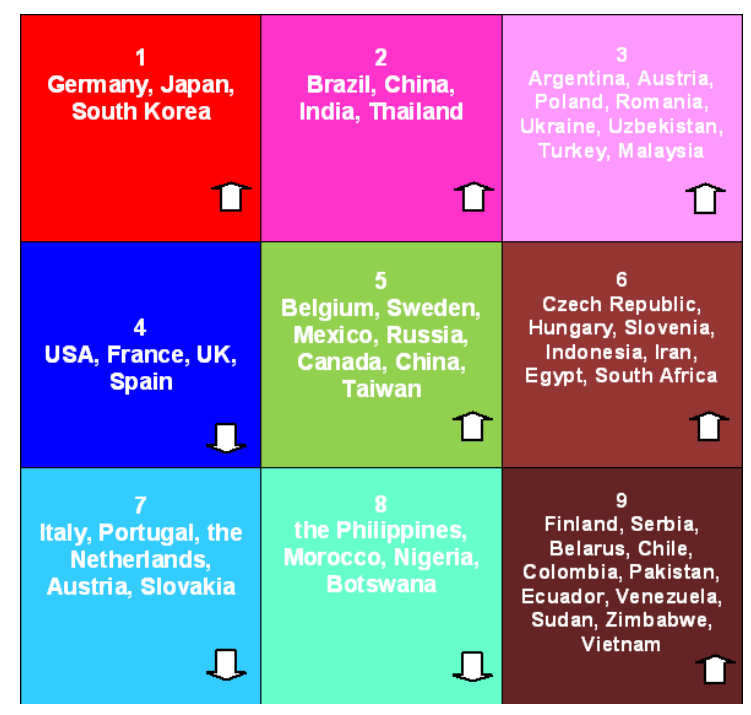

Figure 1. Matrix partitioning of the auto manufacturers

The analysis showed a clear partition of countries into 9 groups (see Figure 1), the characteristic of which is as follows.

Groups $1,2,3,5,6,9$ can be evaluated as a group, "growth", i.e. this country, the proportion of industrial capacity in the world market which is growing, and the three groups - 4,7,8 - group "reduce", whose share in total world production is reduced.

Study each group gives the following results.

The first group can be described as a group of "leaders", it has a high market share and a positive growth rate of vehicles. Index of production of cars per 100 people. residents is high, ranging from 7 to 8.5 cars per 100 inhabitants. The average rate of output growth was $4.2 \%$ for the period under review. Country car manufacturers, are included in this group provide a significant share of the global increase in the production of vehicles (for example, South Korea in 2011 provided more than $9 \%$ of the global increase in the production of cars), and domestic producers in the aggregate have a significant market share. On average, the group, the figure is $10 \%$.

The largest share of the increase in world production provide Brazil and China, the second group, "growth", which can be characterized as "growth leaders". The share of these countries in total world production is as follows: $-11 \%$ for Brazil; $-21 \%$ for China. The average growth rate for the group is $18.3 \%$, while the market share of the group is on average $4.1 \%$ of total world production.

Producing countries are included in this group occupy a large share in the world production of cars, have significant growth rates compared with previous periods, and relatively low (compared to the developed countries) indicator of production of cars per 100 inhabitants (average 0.9 cars per 100 people.).

The reason for the significant growth in vehicle production in the countries of this group is to make them more attractive to car manufacturers, which is based:

- on low labor costs (the average wage in China is 2 times of that in Russia and 26 times less than in the United States and Japan);

- protectionism states that provide significant preferences car manufacturers (the level of import duties on cars with China's accession to the WTO has been fixed at 200\%).

This trend is confirmed by statistics, so, in 2011 more than $10 \%$ of the volume of production companies such as GM, Ford, DaimlerChrysler, Renault were produced in the countries of this group.

Taking into account the huge potential of the economies of India and China - the presence of factors such as competition, cheap labor; low rate of production of cars per 100 people. resident population (India - $0.14 \mathrm{~A} / \mathrm{m}$, China $0.4 \mathrm{a} / \mathrm{m}$ ), and suggest that the development of production cars in these countries will have the current trends, the basis of the relation (2), when the index of production of cars in 100 people values is 1.34 (an existing measure in Brazil), the total production of vehicles in China and India will be 32 million 388 thousand units.

$$
\mathrm{V}=\mathrm{K} * \mathrm{~N}
$$


where: $\mathrm{K}$ - car production (pieces) per 100 inhabitants; $\mathrm{N}$ - Population (people).

While maintaining the current rate of growth, these countries achieved an average of 10 years, i.e. in 2015. In 2015 , the share of China and India in the production of cars will be $32 \%$ of the total world production.

However, only half of the output growth in these countries will be covered by the growth in demand for cars, the rest will be covered by the selection of the market share in other countries, car manufacturers.

In these countries, due to higher labor costs, low efficiency of production, outdated production facilities, manufacturing companies will be forced to cut car production to a minimum.

In the first place, "victims" of growth may be the country that is part of the "reduction" (a group of 4, 7, 8).

One of these groups are developed in the automotive against countries such as the USA, France, UK and Spain.

These countries - car manufacturers have a significant market share, the average for the group, it is more than $7 \%$, but the current dynamics of increase in the volume of cars produced negative. If you change the dynamics of the production of cars in these countries in the positive direction will move these countries in group 1 "leaders."

In case of continued negative dynamics of production of cars, these countries will gradually lose the status quo leading manufacturers in the global market and will go to the group of "moderate growth" group 5 or group "reduction" (Group 7).

Group 7 is characterized by a small fraction of the market, the group average of $0.6 \%$, and the negative dynamics of the production of cars in the group average decline in production is $7.1 \%$. This group is at particular risk of total loss of existing products on the market of cars.

\section{Results}

Russia is among the group of countries, the main characteristic of which is:

- Slight growth rate of car production in the analyzed period, the average for the group of $3.3 \%$;

- Negligible impact of growth of production in these countries on the overall increase in production cars in the world $1.1 \%$.

In general, this group is characterized as a group of "moderate growth".

Despite the positive dynamics of development and position in the market, countries in this group, including Russia, in the absence of positive dynamics to increase market share, as it grows, will lose their positions and will be transferred from "growth" in the group "reduce" - group 7.

This process may result in the fact that the countries in this group will be faced with the fact of loss of existing positions in the global car market and reduce production volume to a certain minimum. Reason for this is that manufacturing companies will bring production to countries with lower costs of production infrastructure and significant government preferences.

Conclusion is confirmed by the analysis of the dynamics of changes in the volume of car production and market share in Canada.

The absence of measures to stimulate the production of cars in Russia may result in the long term to a sharp reduction in the production or transformation of existing production in the "screwdriver" assembly, whose main aim is to obtain tax incentives to reduce the cost of goods manufactured outside the Russian car.

The main characteristic of the producing countries, which are part of these groups - it's a small market share is less than $1.5 \%$.

Pay attention to performance groups "growth" of 3 and 6 Although a small proportion of world production - an average of $0.6 \%$ for both groups of countries, producing countries belonging to these groups have a positive rate of growth of production - $39.6 \%$ for group 3 and over $18.1 \%$ - group 6 .

The growth has a significant impact on the global growth rate of car production in an average $2.9 \%$ for group 3 , and $1.9 \%$ for the group 6 while maintaining and increasing the rate of growth in the long term, countries belonging to these groups may approach to the producer countries in Group 2 or group 5 and take a significant share of the global car market.

Groups 8 and 9 are characterized as a group of "growth" and "reduce", respectively. Common to all these groups is that the dynamics of changes in production (positive or negative) does not affect the change in the rate of growth of world production of cars, i.e. this country are outsiders who do not have a significant impact on the world market and will not have a significant impact on its performance in the short and medium term. 


\section{Conclusion}

Russia is among the group of "limited growth" (Group 5). Countries in this group may lose market share as the growth of production in the "leaders" and the countries' leaders of growth, "the group 1 and 2, so this group of countries should take steps to improve their competitiveness, one of which is the formation of the financial mechanism cost management. Otherwise, the possible scenario is a drop in production to a minimum. The consequence will be a reduction in employment of the active part of the population connected to the automobile business, and a possible crisis economies.

Thus, the article presents the priority strategic directions for Russian companies and the automotive industry held group of car manufacturers on the basis of the matrix BCG in the dominant features to determine the position of the Russian car industry, development prospects and trends of the financial mechanism of formation control in the automotive industry.

\section{References}

Adigamova, F. F., Safiullin, M. A., \& Tufetulov, A. M. (2014). Mechanism of state tax regulation in the global economy. Mediterranean Journal of Social Sciences, 5(24), 193-199. http://dx.doi.org/10.5901/mjss.2014. v5n24p193

Ankudinov, B., \& Lebedev, O. V. (2014). Job insecurity and employees' motivation to engage in professional education. American Journal of Applied Sciences, 11(5), 860-865. http://dx.doi.org/10.3844/ajassp.2014. 860.865

Cabigiosu, A., Zirpoli, F., \& Camuffo, A. (2013). Modularity, interfaces definition and the integration of external sources of innovation in the automotive industry. Research Policy, 42(3), 662-675. http://dx.doi.org/10.1016/j.respol.2012.09.002

Dassisti, M., \& Giovannini, A. (2012). Ontologies for interoperating sustainable manufacturing: New opportunities for the automotive sector. International Journal of Automotive Technology and Management, 12(3), 273-294. http://dx.doi.org/10.1504/IJATM.2012.050359

Giachetti, C. (2012). The relationship between internationalisation and firm performance in the global automotive industry: Who benefits? Who not? International Journal of Automotive Technology and Management, 12(3), 295-311. http://dx.doi.org/10.1504/IJATM.2012.050362

Kurilov, K. Y. (2012). World and Russian automotive industry development perspectives. Studies on Russian Economic Development, 23(5), 478-487. http://dx.doi.org/10.1134/S1075700712050085

New motor vehicle sales in the United States, 1931-2009. Retrieved August 23, 2012, from http://www.WardsAuto.com/Reference Center

Production of vehicles around the world by region, 1951-2009. Retrieved August 23, 2012, from www.WardsAuto.com/Reference Center

Production of vehicles around the world by type, 1951-2009. Retrieved August 23, 2012, from http://www.WardsAuto.com/Reference Center

Registration of vehicles in the world, 2003-2007. Retrieved August 23, 2012, from http://www.WardsAuto.com/Reference Center

Saleeshya, P. G., Austin, D., \& Vamsi, N. (2013). A model to assess the lean capabilities of automotive industries. International Journal of Productivity and Quality Management, 11(2), 195-211. http://dx.doi.org/10.1504/ IJPQM.2013.052024

Serban, V., \& Olaru, M. (2012). Using problem-solving processes and methods in the automotive industry: a successful teamwork towards increasing customer satisfaction. Quality - Access to Success, 13(SUPPL.5), 263-268.

Sewell, E. (2011). Competition and dealership agglomeration in new car markets. Applied Economics Letters, 18(13), 1279-1283. http://dx.doi.org/10.1080/13504851.2010.534054

The global automotive industry. Key indicators. Retrieved January 10, 2012, from http://www.oica.net/category/ economic-contributions/facts-and-figures

The share of car manufacturers on the market of the USA, 1961-2009. Retrieved August 23, 2012, from http://www.WardsAuto.com/Reference Center

The strategy of development of the automotive industry in the Russian Federation for the period up to 2020. 
Retrieved August 23, 2012, from http://www.minpromtorg.gov.ru/ministry/strategic/sectoral/10

Underwood, R. L. (2012). Automotive foreign direct investment in the United States: Economic and market consequences of globalization. Business Horizons, 55(5), 463-474. http://dx.doi.org/10.1016/j.bushor. 2012.04.004

Valitov, S. M., \& Sirazetdinova, A. Z. (2014). Project risks' management model on an industrial entreprise. Asian Social Science, 10(21), 242-249. http://dx.doi.org/10.5539/ass.v10n21p242

World Factbook. Retrieved August 23, 2012, from http://www.cia.gov/library/publications/the-world-factbook

\section{Copyrights}

Copyright for this article is retained by the author(s), with first publication rights granted to the journal.

This is an open-access article distributed under the terms and conditions of the Creative Commons Attribution license (http://creativecommons.org/licenses/by/3.0/). 